\title{
SOCIAL CHARACTERISTICS AND THEIR EFFECT ON SELF-RATED HEALTH IN PERSONS OVER 18 YEARS OF AGE
}

\author{
Joana Simeonova ${ }^{1}$, Angelika Velkova ${ }^{2}$, Penka Kostadinova ${ }^{3}$ \\ ${ }^{1}$ Medical University of Pleven \\ ${ }^{2}$ Medical University of Sofia \\ ${ }^{3}$ RHIF - Pleven
}

\begin{abstract}
INTRODUCTION: Social stratification of people results from differences in education occupation and income, and it exposes the people from lower social classes to different health risks and deprives them of ability to control their health. The aim of this study was to examine the effect of individual social status on selfrated health (SRH). Two hypotheses were tested. First, if some social factors (education, financial resources and monthly income per family member) have direct effects on SRH. Second, if these social factors influence the relationships of psychological stress and some behavioral factors to SRH.
\end{abstract}

MATERIAL AND METHODS: A cross-sectional study was carried out among 90 persons over 18 years of age in 2013. Self-rated health, psychological stress, social status (education, income, property ownership, and qualification) and some behavioral characteristics (body-mass index and fresh vegetable intake) were studied by a semi-structured interview. Data were processed by SPSS.v.19. Descriptive statistics, ANOVA and Kruskall-Wallis tests were used. Finally, Spearman rho test was applied to clarify the strength and direction of association between variables.

RESULTS: Most of the interviewees (47.8\%) assessed their health as good. Stratification by some basic social characteristics showed that $5.6 \%$ of them had elementary education, $12.4 \%$ were unemployed. One third of the group under study existed on monthly income less than 310 BGN, 30\% defined their financial resources as insufficient, $\mathbf{1 6 . 6 \%}$ lived in rented accommodation. Every third person reported a disparity between the current job position and the owned professional competences. Education and financial resources were the variables significantly associated with self-rated health - those with elementary education and those who had insufficient financial resources perceived their health negatively more often $(p=0.001)$. Symmetrical distribution of poor SRH among the groups with lower incomes explained partly the lack of significant differences between groups $(\mathrm{p}=\mathbf{0 . 4 6 9})$.

CONCLUSION: Education and financial resources were significantly associated with self-rated health among all studied social factors.

Keywords: self-rated health, social status, psychological stress

Address for correspondence:

Joana Simeonova

Medical University - Pleven

1 Sv. Kliment Ohridski Str.

5800 Pleven, Bulgaria

e-mail:goana@dir.bg

Received: May 4, 2015

Accepted: June 23, 2015

Scripta Scientifica Salutis Publicae, vol. 1, №1, 2015, 15-20

Copyright ( ) Medical University of Varna 


\section{INTRODUCTION}

One of the basic mechanisms through which the social inequalities influence on health is stratification of people in social classes according to their control over resources. This social stratification results from differences in education, occupation and income. It exposes the people from lower social classes to different health risks and deprives them of ability to control their health. Many studies established that people with lower socioeconomic status (SES) assess their health more frequently as lower compared to those with higher SES. The aim of the present study is to examine the effect of individual social status on self-rated health (SRH). We will test two hypotheses. First, if some social factors (education, financial resources and monthly income per family member) have direct effects on SRH. Second, if these social factors influence the relationships of psychological stress and some behavioral factors to SRH.

\section{MATERIAL AND METHODS}

A semi-structured interview was carried-out among 90 persons over 18 years of age in 2013. Initially 100 people of that age were invited to take part in the study. They were randomly selected among the inhabitants of two municipalities in the region of Pleven. For the selection of the study sample we applied the age, sex and residence composition of Bulgarian population in 2012. Some sociodemographic characteristics of the group are presented in Table 1. Over 70 percent of interviewees were urban residents. The interviewees were classified in two age groups: 18-59 and over 60 years. We collected personal information about the completed educational level and social status (employed, unemployed, re-

Table 1. Sociodemographic characteristics of interviewees $(n=90)$

\begin{tabular}{|c|c|c|c|c|c|}
\hline Variable & $\begin{array}{c}\text { Number } \\
(\%)\end{array}$ & Variable & $\begin{array}{c}\text { Number } \\
(\%)\end{array}$ & Variable & $\begin{array}{c}\text { Number } \\
(\%)\end{array}$ \\
\hline Residence & & Education & & Social status & \\
\hline City & $33(36.7)$ & Elementary education & $5(5.6)$ & Employed & $49(55.1)$ \\
\hline including by gender: & $33(100.0)$ & Secondary education & $48(53.3)$ & Unemployed & $11(12.4)$ \\
\hline * male & $12(36.4)$ & Higher education & $37(41.1)$ & Retired & $27(30.3)$ \\
\hline * female & $21(63.6)$ & & & Retired to illness & $2(2.2)$ \\
\hline $\begin{array}{l}\text { including by age: } \\
\text { * under } 60 \text { yrs } \\
\text { * over } 60 \text { yrs }\end{array}$ & $\begin{array}{c}33(100.0) \\
25(75.8) \\
8(24.2)\end{array}$ & $\begin{array}{l}\text { Month income } \\
\leq 310 \mathrm{BGN} \\
311-550 \mathrm{BGN} \\
551-1000 \mathrm{BGN} \\
\geq 1000 \mathrm{BGN}\end{array}$ & $\begin{array}{c}27(30.0) \\
46(51.1) \\
15(16.7) \\
2(2.2)\end{array}$ & $\begin{array}{l}\text { Qualification } \\
\text { Overqualified } \\
\text { worker } \\
\text { Qualified worker } \\
\text { Lower qualified }\end{array}$ & $\begin{array}{c}5(10.0) \\
35(70.0) \\
10(20.0)\end{array}$ \\
\hline Town & $\begin{array}{l}33(36.7) \\
33(100.0)\end{array}$ & Financial resources & & $\begin{array}{l}\text { worker } \\
\text { Home }\end{array}$ & \\
\hline $\begin{array}{l}\text { Inciuaing by genaer: } \\
\text { * male }\end{array}$ & $\begin{array}{l}14(42.4) \\
19(57.6)\end{array}$ & Sufficient only for & $37(41.1)$ & Own home & $73(81.1)$ \\
\hline * female & $19(5 \% .6)$ & $\begin{array}{l}\text { basic needs } \\
\text { Enough }\end{array}$ & $26(28.9)$ & $\begin{array}{l}\text { Lived with } \\
\text { relatives }\end{array}$ & $\begin{array}{c}4(4.4) \\
11(12.2)\end{array}$ \\
\hline $\begin{array}{l}\text { including by age: } \\
* \text { under } 60 \mathrm{yrs} \\
\text { * over } 60 \mathrm{yrs}\end{array}$ & $\begin{array}{c}33(100.0) \\
25(75.8) \\
8(24.2)\end{array}$ & $\begin{array}{l}\text { Insufficient } \\
\text { Extremely } \\
\text { insufficient }\end{array}$ & $\begin{array}{c}25(27.8) \\
2(2.2)\end{array}$ & $\begin{array}{l}\text { Lived rent } \\
\text { Other }\end{array}$ & $2(2.2)$ \\
\hline Village & $24(26.7)$ & & & & \\
\hline including by gender: & $24(100.0)$ & & & & \\
\hline * male & $5(20.8)$ & & & & \\
\hline * female & $19(79.2)$ & & & & \\
\hline $\begin{array}{c}\text { including by age: } \\
* \text { under } 60 \mathrm{yrs} \\
* \text { over } 60 \mathrm{yrs}\end{array}$ & $\begin{array}{c}24(100.0) \\
16(66.7) \\
8(33.3)\end{array}$ & & & & \\
\hline
\end{tabular}


Joana Simeonova, Angelika Velkova, Penka Kostadinova

tired or retired due to illness). Three variables were used to measure material status of the participants - monthly income per family member, financial resources and property ownership. The interviewees were divided into three groups according to their professional qualification. Self-perceived health was assessed by the question „How do you assess your health at present?" in 5 categories: excellent health, very good health, good health, fair health and poor health. Individual index of psychological stress was measured by Perceived Stress Scale (Cochen, 1983). The index was calculated as a sum of the points given by the interviewees to each of 10 questions, with a maximum of points. A higher index meant a higher level of psychological stress. The mean index of the group was 20.5 \pm 4 .3. Body-mass index (BMI) was calculated using a formula weight $(\mathrm{kg}) /$ height $\left(\mathrm{m}^{2}\right)$ and the individuals were classified according to the international BMI scale. We also collected information about the weekly intake of fresh vegetables (in number of servings). Data were processed by SPSS.v.19. Descriptive statistics, ANOVA and Kruskall-Wallis tests were used in the analyses. Spearman rho test was taken to clarify the magnitude and the direction of the studied association.

\section{RESULTS}

Almost 6 percent of the interviewees had elementary education and $12.4 \%$ were unemployed. One third of the group existed on monthly income less than 310 BGN, 30\% defined their financial resources as insufficient, $18.9 \%$ did not have their own housing. Every third person reported a disparity between the current job position and the owned professional competences (Table 1).

Most interviewees (47.8\%) assessed their health as good. Almost $27 \%$ of the group evaluated their health negatively, $23.3 \%$ as fair, and only $3.3 \%$ - as poor (Fig. 1). The age determined the way people perceived their health - the proportion of negative rates was over 3 times higher at older ages than at the younger ones (Fig. 2). We did not find significant differences between the SRH categories by sex ( $>0.05)$.

We examined whether the educational differences determine any differences in subjective health (Fig. 3). The findings showed that interviewees with elementary education perceived their health more frequently as poor than those with higher educa-

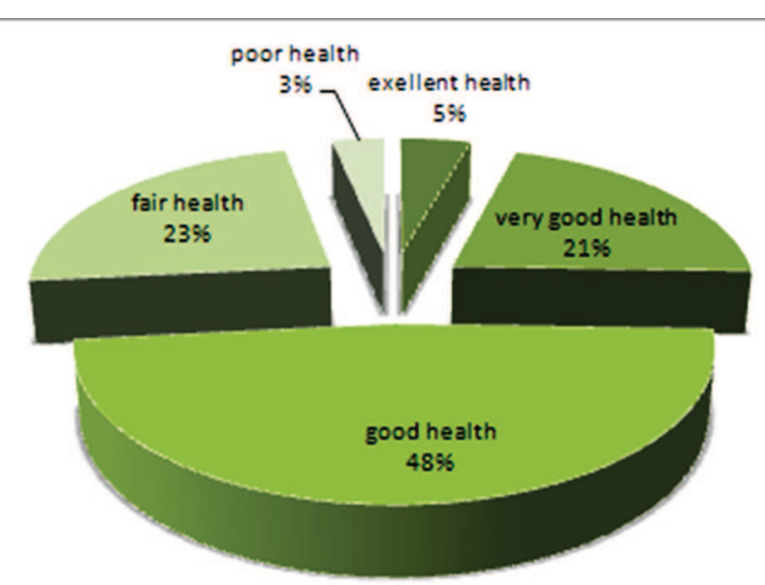

Fig. 1. Structure of interviewees according to their self-rated health (\%)

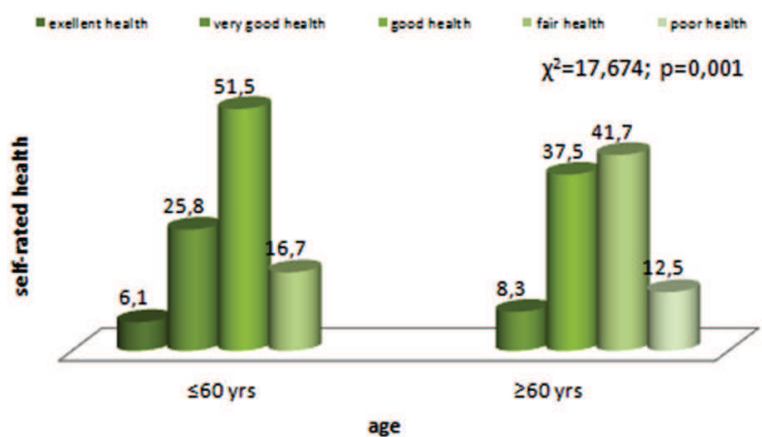

Fig. 2. Distribution of interviewees according to age and SRH (\%)

tion $(\mathrm{p}<0.001)$. We expected to find out similar association with the income per family member, but we could not prove it $(\mathrm{p}>0.05)$. Probably the symmetrical distribution of poor SRH in the two lower income groups explains partly the absence of significant differences between the groups ( $\mathrm{p}=0.469)$.

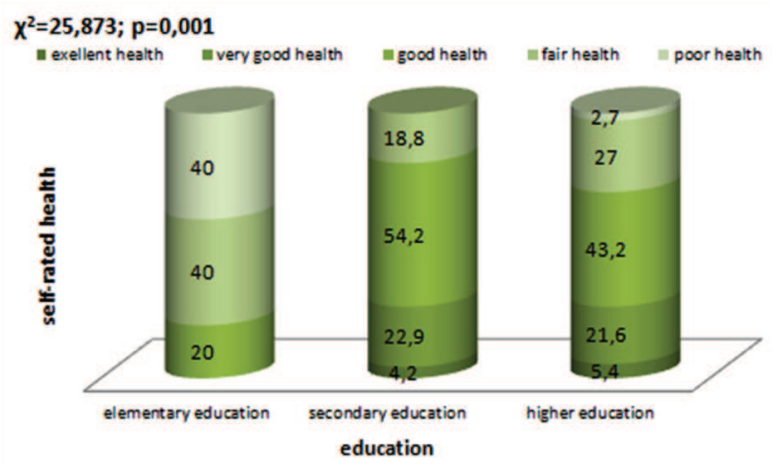

Fig. 3. Distribution of interviewees according to educational attainment and their SPH (\%) 


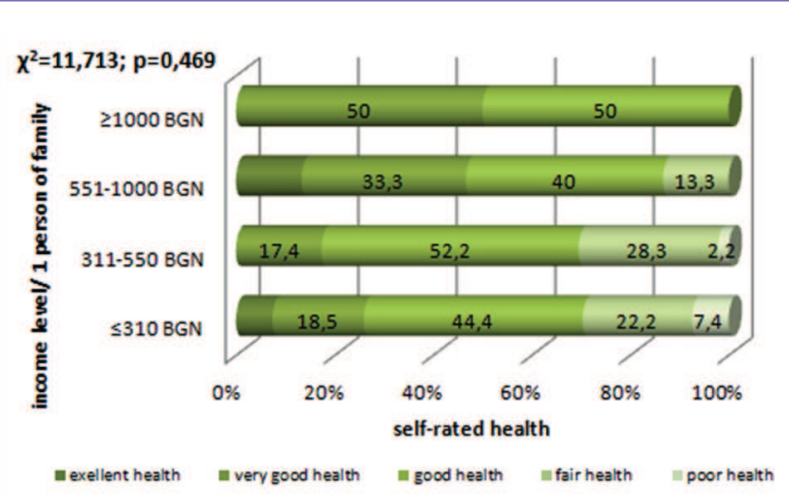

Fig. 4. Distribution of interviewees according to family financial resources and SRH (\%) $\mathrm{p}=0.008$ ). Controlling for the effect of education did not changed the power and direction of the association $(r=.245 ; \mathrm{p}=0.025)$, thus rejecting that the education mediated association between the psychological stress and SRH. The same finding holds when controlling for the effect of family income $(\mathrm{r}=.252$; $\mathrm{p}=0.018$ ).

\section{DISCUSSION}

Self-rated health is one of the most commonly used integrated indicators for measuring individual and population health. The indicator provides information about personal notions, expectations and

Table 2. Data on bivariate correlation between SRH and some psycho-behavior characteristics of the interviewees (Spearman rho test)

\begin{tabular}{llcc|cccc} 
& Stress & Stress $^{* * *}$ & BMI & BMI*** & $\begin{array}{c}\text { Fresh } \\
\text { vegetable }\end{array}$ & $\begin{array}{c}\text { Fresh } \\
\text { vegetable }^{* * *}\end{array}$ \\
\hline $\begin{array}{l}\text { Self-rated } \\
\text { health }\end{array}$ & $\begin{array}{l}\text { Correlation } \\
\text { Coefficient }\end{array}$ & $\mathbf{2 8 0}^{* *}$ & $\mathbf{2 4 5}$ &, 049 &, 053 &, 003 &, 040 \\
& $\begin{array}{l}\text { Sig. } \\
(2 \text {-tailed })\end{array}$ & $\mathbf{, 0 0 8}$ & $\mathbf{, 0 2 5}$ &, 656 &, 635 &, 975 &, 715 \\
& $\mathrm{~N}$ & 89 & 82 & 86 & 82 & 90 & 82 \\
\hline
\end{tabular}

${ }^{* *}$ Correlation is significant at the 0.01 level (2-tailed). ${ }^{a}$ controlled education

When we compared the interviewees in respect to their financial resources and SRH we found that the majority of those experiencing insufficient availability of resources reported fair and poor health (Fig. 4). Although $18.9 \%$ of study participants were living in rented accommodation, the lack of private housing was not significantly associated with more negative SRH ( $\mathrm{p}=0.178)$. Significant differences were not detected in respect to the reported social group and the SRH ( $>>0.05)$. In spite of the fact that $40 \%$ of the lower qualified workers rated their health as fair, the level of professional qualification did not determined the SRH $(\mathrm{p}=0.228)$.

In the process of statistical analysis the applied ANOVA, chi-square and Kruskal-Wallis tests revealed significant relationships between some psycho-behavioral characteristics (psychological stress, BMI, fresh vegetable intake) and SRH. Since many investigators found that these factors are involved in the mechanism SES - physical health - SRH, we performed bivariate correlation analysis (Table 2). It confirmed a significant weak association only between the Index of psychological stress and SRH $(r=.280$; preferences to good health which resulted from the individual psychological orientation, values and disease experience, from the prevailing socio-cultural norms and from the shared resources and knowledge between the community members $(4,5,20,21,25,27)$. Almost $50 \%$ of our interviewees perceived their health as good. The proportion of persons with lower SRH was $26.6 \%$. A clear association was observed between the subjective health and age - persons over 60 years of age used 3 times more frequently the categories „fair health" and "poor health" than persons at younger age. Similar finding was reported in many articles and it was explained by health trajectory of persons $(7,9,11,29)$.

Clarifying the role of social inequalities on selfrated health requires studying the mechanism by which the education, income and occupation divide people in social classes and predetermine the occurrence of different health problems. In most cases the social gradient influences on subjective health indirectly. Higher level of psychological stress was reported by people with lower SES, risky health behavior and limited access to health services and social 
Joana Simeonova, Angelika Velkova, Penka Kostadinova

services. It was associated with many psychosomatic diseases and functional deficits $(8,10,12,16,23)$. Like others $(9,10,15)$ we determined that lower education was significantly associated with more negative SRH. Some researchers affirmed that education has mediating role in the association physical health - SRH $(10,16,17)$, we could not confirm that. A weak correlation was found out between psychological stress index and SRH. That correlation was kept when we accounted for the effect of the education.

The income influence on SRH was studied with two indicators (objective and subjective) and we established that insufficient family financial resources determined more pessimistic self-rated health. The same inference came from other studies $(3,6)$. They found that the subjective SES measures were more appropriate in studying the influence on $\mathrm{SRH}$, especially in respondents with lower education; in persons who have never worked; or in those who were dependent on the financial support of their children.

It was proved that people who do not work (unemployed, retired due to illness, retirees) assess more frequently their health as poor. The cause of these findings is the lower income level and its negative health effects $(1,2,9,14,19,24,26)$. However, we did not find significant association between the social group and SRH. In our study the professional qualification was not a determinant of SRH, although some publications present evidences about negative self-rated health of lower qualified and overqualified workers $(13,18,23,28)$.

\section{CONCLUSION}

The present study tested two research hypotheses. Among the studied social factors education and the family financial resources were significantly associated with self-rated health. We failed to prove the mediating effect of these social factors in the associations between some psycho-behavioral factors and $\mathrm{SRH}$. Our findings are possibly due to the complex interrelations between the variables and the limitations of the study design we employed. The role of SES in that web of associations has to be tested further in a longitudinal study by elaborated statistical analysis. That will clarify the independent effect of education, income, professional qualification and several psycho-behavioral factors on SRH.

\section{REFERENCES}

1. Vankova D. Kachestvo na zhivot, svarzano sas zdraveto (ili Kachestvo na zhivot, zdravey!). Sotsialna meditsina. 2010;1:6-9. Bulgarian.

2. Ahs AMH, Westerling R. Self-rated health in relation to employment status during periods of high and of low levels of unemployment. European Journal of Public Health. 2006;16(3):295-305.

3. Balabanova DC. Self-Reported Health in Bulgaria: levels and determinants. Scand J Public Health. 2002;30(4):306-312.

4. Bowling A. Just one question: If one question works, why ask several? J Epidemiol Community Health. 2005;59:342-345.

5. Brown JS, Pan X, Chahal J, Bardo AR, Lynch SM. Quality of life and Self-related health among Adults Aged 60 and Older in Ten Major World Metropolises, Proceeding of the Population Association of America; 2014 May 1-3; Boston.

6. Collins A, Goldman N. Perceived Social Position and Health in Older Adults. Soc Sci Med. 2008 Feb;66(3):536-544.

7. Dewey ME, Parker CJ, the Analysis Group of the MRC-CFA Study. Survey into health problems of elderly people: a comparison of self-report with proxy information. Int. J. Epidemiol. 2000;29(4):698-703.

8. Filho APC, Lebrao ML, Kawachi I. Income inequality and elderly self-rated health in Sao Paolo, Brazil. Annals of Epidemiology. 2012;22:863-867.

9. Kaleta D, Makowiec-Dabrowska T, Jegier A. Employment status and self-rated health. IJOMEH. 2008;21(3):27-236

10. Kaleta D, Polanska K, Dzankovska-Zaborsczyk E, Wojciech H, Wojciech D. Factors influencing self-perception of health status. Cent Eur J Public Health. 2009;17 (3):122-127.

11. Kivinen P, Halonen P, Eronen N, Nissinen A. Selfrated health, physician-rated health and associated factors among elderly men: the Finnish cohorts of the Seven Countries Study. Age and ageing. 1998;27(1):41-47.

12. Mackenbach J, Martikainen P, Looman C WN, J. Dalstra AA, Kunst A, EL and members of the SEdHA working group. The shape of the relationship between income and self-assessed health: an international study. Int J Epidemiol. 2005 Apr;34(2):286-93. 
13. Mahmoud N. Self-Rated Health status and smoking [dissertation]; San Diego State University; 2011.

14. Molarius A, Beglund $K$, Eriksson C, Lambe M, Nordström E, Eriksson HG, et al. Socioeconomic conditions, lifestyle factors, and self-rated health among men and women in Sweden. European Journal of Public Health. 2006;17(2):125-133.

15. Montazeri A, Goshtasebi A, Vahdaninia M. Educational inequalities in self-reported health in a general Iranian population. BMC Research Notes. 2008; 1:50.

16. Monteiro CR, Santos GMM, Cyrillo DC. Factors Associated with Self-Perceived Health among Women Attending a Sports Fitness Centre. International Journal of Humanities and Social Science. 2012;2(24):38-45.

17. Nguyen L, White M. Health status, Urban ward Migration, and Government Policy in Urban Areas in Vietnam. Proceedings of the IUSPP Conference: Southeast Asian Population in a Changing Asian Context, Bangkok, Thailand; June, 2002.

18. Pappas NA, Alamonos Y, Dimoliatis I DK. Self-rated health, work characteristics and health-related behaviors among nurses in Greece: a cross-sectional study. BMC Nursing. 2005;4:8.

19. Precupetu I, Vasile M, Vlase I. Individual and Contextual Factors in Self-Rated Health Inequalities: A Comparison between Romania, 10NMS, and EU15. Expert Projects Publishing House. 2013;41:28-39.

20. Sargent-Cox KA, Anstey KJ, Luszcz MA. The choice of self-rated health measures matter when predicting mortality: evidence from 10 years follow-up of the Australian longitudinal study of aging. BMC Geriatrics. 2010;10:18.

21. Schnittker J. When Mental Health Becomes Health: Age and the Shifting Meaning of Self-Evaluations of General Health. The Milbank Quarterly. 2005;83(3):397-423.

22. Simon JG, Boer JB, Joung IMA, Bosma H, Makenbach JP. How is your health in general? A qualitative study on self-assessment health. European Journal of Public Health. 2005;15(2):200-208.

23. Smith P, Frank J. When aspirations and achievements don't meet. A longitudinal examination of the differential effect of education and occupational attainment on declines in self-rated health among Canadian labour force participants. Int J Epidemiol. 2005 Aug;34(4):827-34.
24. Taloyan M, Wajngot A, Johansson S, Tovi J, Sundquist J. Poor self-rated health in adult patients with type 2 diabetes in the town of Sodertalje: a cross-sectional study. Scand J Prim Health Care. 2010;28(4):216-220.

25. Uden AL, Elofsson S. Do Different Factors Explain Self-Rated Health in Men and Women? Gend Med. 2006 Dec;3(4):295-308.

26. Virtanen P, Liukkonen V, Vahtera J, et al. Health inequalities in the workforce: the labour market core-periphery structure. Int J Epidemiol2003;32:1015-21.

27. Vuorizalmi M. Examining Self-Rated Health in Old Age. Methodological Study of Survey Questions [dissertation]; University of Tampere; 2007.

28. Winnersjo R, Leon AP, Soares JF, Macassa G. Violence and Self-Reported Health: Does Individual Socioeconomic Position Matter? J Inj Violence Res. 2012 Jul;4(2): 87-95.

29. Yiengprugsawan V, Lim L LY, Carmichael GA, Sidorenko A, Sleigh AC. Measuring and decomposing inequity in self-reported morbidity and self-assessed health in Thailand. International Journal for Equity in Health. 2007;6:23. 